\title{
DISPUTED ASPECTS OF THE REPUTATION MANAGEMENT IMPLEMENTATION
}

\author{
VITALIY SHKROMYDA
}

\begin{abstract}
The recognition of the company and its products, its positive perception among stakeholders are important drivers of sustainable development, which together generate constant sales, provide high margins and strengthen competitive positions in the relevant market. The key factor in this success is the company's impeccable corporate reputation, the importance and role of which is more and more attested by the researchers in their publications, both on the theoretical and practical levels.

Reputation management as a separate component of the company's governance system is accompanied by debatable issues regarding its separation and independence. The sources on this subject trace differing views among scholars and practitioners to be agreed. Some researchers attribute reputation management to the "public relations" and "corporate relations" competencies and, while others single out and prove its independence as a separate management system, which has its own purpose and specific tasks.

The study proved that reputation management is an independent component of the company's governance system. The substantiation of such a statement is revealed by the essential content of corporate reputation, is accompanied by the clearly outlined goal and performed functions, as well as the justification of the importance of reputation management in the company's activities and its strategic development. We agree that reputation management is deeply integrated with other components of the governance system, such as "public relations", "corporate communications" and "corporate relations", as a result of which they are often equated. However, these components of the governance system differ from each other both in content and purpose. It is established that the highest goal of reputation management is to build a corporate reputation and achieve the key stakeholders' loyalty.

The scientific value of the research is to supplement the theoretical and methodological basis of reputation management, in particular in terms of addressing the disputed aspects of its implementation in the companies' activities.
\end{abstract}

Keywords: corporate reputation, reputation management, public relations, discussion.

JEL Classification: D91, M14, M21, M31.

\section{INTRODUCTION}

Ensuring successful operations in today's competitive environment urges companies to significantly reconsider traditional management approaches. The existing trends, accompanied by 
permanent variability and uncertainty, directly or indirectly affect management methods, which as needed are forced to improve and adjust to existing changes.

Recently, there has been a growing interest of business representatives in their reputation and its impact on the current activities of the company. Realizing the importance and value of the latter, the governing bodies of most business structures are trying to build an impeccable reputation, strengthen their presence and use it effectively. Of course, the process of forming the competitive advantages, including reputation, requires a set of knowledge and competencies that help identify the object of study, describe the classification features and inherent properties, identify structural elements, as well as properly select methodological approaches to developing and making effective management decisions. In this context, the introduction of reputation management in the activities of companies and the formation of its theoretical and methodological foundations are relevant and requires further research.

Along with this, reputation management as a separate component of the company's governance system is accompanied by debatable issues regarding its separation and independence. Thus, in specialized sources, we can find different opinions of scholars and practitioners, where reputation management is either attributed to the competencies of the traditional field of "public relations / corporate communications", or identified as and proved to be an independent separate management system, which has its own purpose and specific objectives. We believe that the implementation of reputation management in order to construct the company's impeccable reputation makes it necessary to consider and resolve controversial aspects at both the theoretical and practical levels.

\section{THEORETICAL BACKGROUND}

Addressing the issues of building the companies' impeccable reputation as one of the key drivers of their sustainable development is caused by the permanent manifestations of the crisis phenomena in the economy and their impact on the activities of business entities. A number of foreign scholars, namely G. Dowling, C. Fombrun, C. Genasi, M. Goldberg, B. Lafferty, G. Marken, P. Nakra, K. Wiedmann, in their works pay special attention to the problems of constructing corporate reputation and developing reputation management. Domestic researchers L. Batchenko, N.E. Deeva, O. Dubrova, L. Gonchar, O. Rodionov and others are also actively involved in solving the above mentioned problems. Statements proving the opposite ideas and treating corporate reputation as the part of "public relations" and "corporate communications" can be traced in the publications by S. Ewen, D. Finn, J. Grunig, J. Hutton, M. Kent, D. Lattimore, D. Newsom, K. Sriramesh.

\section{Research Objective, Methodology and Data}

The purpose of the study is to address the issue of the inconsistency of the researchers' views on singling out reputation management and prove its independence as a separate management system. The achievement of the outlined goal is possible by revealing the essential content of corporate reputation and substantiating its importance in the company's activities and achieving the set strategic goals.

The research is based on the use of general scientific methods and techniques, such as the method of generalization and systematization - in analyzing scientific papers on the subject, the study of the essence and importance of corporate reputation, theoretical foundations of reputation management; as well as of the abstract-logical method and the method of descriptive reflection - in the construction of the illustration material and the formation of the author's statements and conclusions.

\section{RESUlTS AND Discussion}

Reputation management, like any management process, involves a focus on achieving goals. We believe that the priori strategic goal of such management is to form and maintain the trust and loyalty 
of key stakeholders of the company. In other words, the highest degree of the impeccable reputation of the company is a stable commitment and unconditional loyalty of its contact groups.

The best foreign practices show that theorists and practitioners justify in their researches the need for reputation management and prove the importance and impact of the latter on the company's activities. G. Stigler, for instance, mentions that in the conditions of the company's impeccable corporate reputation there is an opportunity to reduce the cost of production per unit of output, which has a positive effect on performance [1]. In this case, it should be noted that the researcher does not mention how and in what chain sequence the mentioned effect is achieved.

In turn, the scientific publications by G. Dowling [2], S. Caminiti [3], S. Preece [4], C. Eidson [5] and P. Nakra [6] testify to the significant influence of the company's positive reputation in the struggle for qualified personnel, promoting the employment of highly productive employees. Here it is worth agreeing with the opinion of the researchers, since such a statement is especially relevant in a period of labor shortages of various qualifications and a sharp struggle for them.

M. Goldberg [7], C. Fombrun [8] and B. Lafferty [9] note that the company's strong reputation has a positive effect on consumers, increases their confidence in products and encourages regular purchases. This approach ensures that companies retain regular customers, as noted by S. Caminiti [3] and S. Preece [4], and, according to B. Klein [10] and P. Milgrom [11], allows you to get a price premium in the form of additional markups. Under such conditions, according to P. Roberts and G. Dowling [12], a good corporate reputation over time allows the company to increase profitability and make windfallprofits.

It is known that the company's reputation appears at the same time with its creation and is accompanied throughout all cycles of its activity. This presence of the company's intangible assets forces its governing bodies from the first days of operation to weigh their own behavior and, of course, the behavior of other market participants and coordinate their actions with the target groups from the standpoint of reputational risks and threats [13].

A key element of this relationship is information that, on the one hand, expresses the contact groups' expectations and, on the other hand, reflects the company's desire to meet existing expectations. Delivering the necessary information about the required content to certain users requires some effort and costs. For example, a company, engaging in philanthropy and other socially significant activities in order to build its reputation, is forced to spend resources on publicizing and disseminating these actions among stakeholders by contributing to the media, being mentioned in blogs, posting on social media, etc. In other words, the implementation of charitable and social activities and their inclusion in the company's reputational assets requires additional costs and efforts. On the contrary, the governing bodies caring about the reputation of their own company, making a mistake related to their activity, is forced to respond immediately and make significant efforts (spend costs) to refute the information, which usually spreads quickly in the light of negative events and, often, scandalous sensations.

In summary, we can conclude that the company's good and impeccable reputation is a precious good, the value of which is expressed in the cost and time dimensions. After all, the company's significant expenditure of appropriate resources and time is required both at the stage of the formation and building of its own positive reputation, and at the stage of its maintenance and preservation. We believe that in this context, the determining and effective factor is the communication between the company and the stakeholders, which provide the exchange of necessary information and whose capacity determines the number of resources and time required to build and maintain the company's reputation.

The word "communication" comes from the Latin "communico", which means a message, connection, communication and in a broad sense - a term that describes human interaction in the world. The modern philosophical interpretation treats it primarily as a sign of constructive interaction of individuals, social groups, nations and ethnic groups, which develops on the basis of tolerance and understanding [14]. It can be stated that reputation is formed in the process of communication through the perception and evaluation of information about the company's activities by various contact groups. 
Under such conditions, well-established communication is a means of both the formation of reputation and the implementation of reputation management.

A historical review of scientific publications shows that the researchers used to have a certain inconsistency of their views on singling out reputation management as a separate component of the company's governance system. This position of some researchers $[15,16,17,18]$ is explained by the fact that the company's "reputation management" is part of "corporate relations" and "corporate communication", i.e. it lies within the competence of the traditional industry "social relations" or "public relations". The evidence of this, in their opinion, is the companies' widespread practice of creating relevant departments, divisions or individual public relations (PR) positions, while the creation of reputation management positions is not practiced.

In this regard, J. Hutton noted that "... the growth of "reputation management", "perception management" and "image management" is a dangerous trend for the industry because they came for the wrong reasons. Most managers who have poor public relations skills think superficially without understanding the differences between "image" and "perception", and follow advice of advertising agencies, which benefit from using these terms to diversify their activities [19].

D. Finn [20], S. Ewen [21] and D. Newsom [22] shared the same view, noting that "image" and "reputation" are not directly manageable because they are the result of strategic and, at the same time, daily behavior of the company. According to them, reputation management can be compared to trying to manage one's own popularity.

At the same time, there are opposing views of other researchers and practitioners who jointly argue for a separate self-sufficient branch of management - reputation management, which is outlined and separated from the traditional field of "public relations" by setting its own goals and solving its own range of tasks.

The well-known investor and philanthropist Warren Buffett is a proponent of the need to build and maintain the company's corporate reputation, arguing that "the loss of reputation is a much greater disaster for the company than the loss of funds" [23]. He also adds that "It takes 20 years to build a reputation and five minutes to ruin it. If you think about that, you'll do things differently". Thus, W. Buffett emphasizes the separation of a particular area of management and the importance of managing the company's reputation.

G. Marken believes that the company's reputation is built and managed through small day-to-day activities. At the same time, he notes that reputation is built by answering every phone call, every email, as well as by every product release, every decision made and every action taken [24]. That is, the researcher emphasizes that the creation and management of the company's reputation is a long-term and daily phenomenon in the course of each business transaction. This approach is shared by C. Genasi who warns that "the quality of communication must be maintained by the quality of action" [25]. His position is that reputation management should be seen as a process that is constantly close to the dayto-day running of the business. An important rule should be compliance with the company's behavior in the market, the published plans and stated intentions.

The growing need for reputation management is noted in their empirical studies by K. Wiedmann and H. Buxel on the example of the German companies [26]. The researchers also note that the scale of implementation of reputation management is directly proportional to the level of competition in the relevant market, where these companies are positioned.

In addition to the theoretical substantiation and generalizations, the importance of reputation management among professionals and the need for its implementation in practice is quite convincingly discussed. In this context, we should mention the thematic international conference held in 2009 by the authoritative association of insurers The Geneva Association, which was devoted to the issues of reputation and reputation risk management [27]. In their report, R. Eccles and M. Vollbracht focused on reputation management and recommended that companies strengthen corporate communications to inform stakeholders and thus manage reputational risks. They suggest focusing on disseminating messages that meet the expectations of the interested counterparties. At the time, Swiss Re P. Forstmoser and N. Herger, advocated a "triple line" of reputation management aimed at 
strengthening the control over the relations between stakeholders and mass media. Based on the experience of Swiss Re, they propose the implementation of reputation management through corporate citizenship, sustainability management, corporate compliance and social significance.

Thus, "public relations / corporate communications" can be embodied in a process where "reputation" is one of the effective indicators of such a process or a tool of reputation management.

A review of the Ukrainian researchers' publications on reputation management and prospects for its implementation suggests a relatively new direction of domestic research. The first articles on corporate reputation began to appear in the early 2000s. Among the first researchers was O. Rodionov, who published his own paper on this subject and pointed out that "... reputation management is a permanent comprehensive process of forming and maintaining a positive public perception of the company and its products, creating a commercial and financial result and long-term credit of trust to the interested contact audiences and society in general" [28].

O. Dubrova offers her own approach to reputation management, which aims at forming and strengthening reputation [29]. In general, this position is correct because it expresses the purpose of such management. In their own research, L. Batchenko and L. Honchar note that "... reputation management is a complex business process of the higher governance, the complex and multifaceted one, requiring a systematic approach, strategic vision and understanding of the direction vector, the ability to select the optimal set of communication tools, etc." [30]. At the same time, as the researchers state, reputation management is a long-term strategy that involves the creation, control and maintenance of the necessary image of the company, and prevents reputation from spontaneous forming.

N. Dyeyeva and V. Grabchak's prove the need of implementing reputation management, which involves “... the process of planning, organizing, implementing and monitoring the company's reputation in order to achieve a positive reputation and minimize reputational risks". At the same time, the researchers note that the effective reputation management involves its implementation on an ongoing basis, i.e. "... the company's purposeful and organized acquiring holistic, stable traits and qualities necessary for its successful operation, taking into account the impact of the environmental factors" [31].

As we can see, the mentioned theoretical and practical tendencies in the foreign and domestic scientific dimension argue the need to single out a separate area of management, namely - reputation management, which, we believe, has its purpose, tasks, functions, tools, etc. We agree that it is impossible to directly manage the company's corporate reputation, because it is unreal to manage a set of opinions, impressions and expectations of individuals or groups of people [22, 20,21]. However, we understand that the factors of such a public opinion, emotional perception or rational judgment are the results and consequences of the company's close relations with contact groups, the level and quality of which depend on the management decisions, and therefore are relevant and manageable in accordance with the commercial goals and objectives. For such reasons, it can be argued that it is more correct to use the phrase "management of factors (drivers) of the company's corporate reputation".

It is established that in the economic scientific sources we may often encounter the concepts of "reputation governance" and "reputation management", which are often misused by the authors of various publications. We believe that this approach to "reputation" is correct, although the etymological meaning of the process of "governing" in general is broader and "covers objects of both living and non-living origin" [32]. Management, in turn, is part of a system where the objects of management are business relationships and organizational structures [33].

Given the above, we propose an author's definition of "reputation management", which should be understood as a separate segment of the company's governance system, which is based on the interdisciplinary approach and with the use of information and communication resources allows you to build and maintain the expected corporate reputation.

The visualization of such a statement is presented in Fig. 1. 


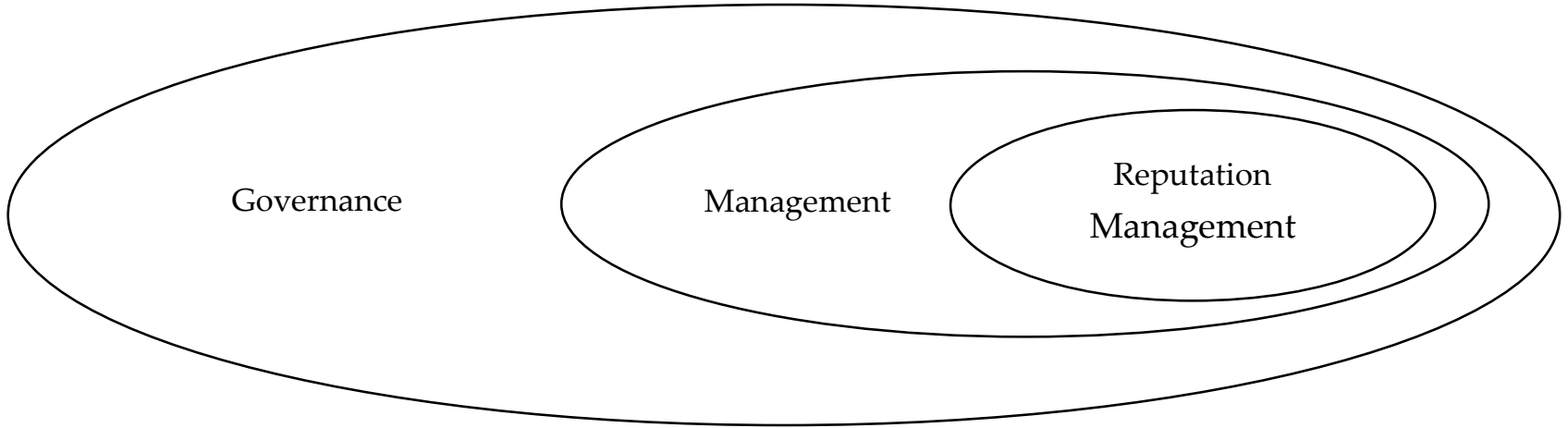

Fig. 1. The place of reputation management in the coordinate system of the process of the company' governance.

Source: developed by the author.

In summary, it should be noted that reputation management is an independent component of the governance system, which has its own purpose and objectives, is characterized by specific features that distinguish it from other components, and plays a key role in achieving the company's strategic goals. In this context, the prerequisites for the introduction and application of reputation management in the modern realities of the business environment are:

- oversaturation of markets and permanent growth of competition for consumers;

- free access to any information through the Internet environment and openness to the outside world;

- public demand for transparency of economic activity and involvement of companies in the joint solution of environmental and other social issues.

\section{CONCLUSIONS}

1. The introduction of reputation management in the course of the company's activities should be accompanied by obtaining the expected results from the implementation of such measures. It is determined that the implementation of management decisions in a given direction provides usefulness and number of benefits that ultimately contribute to the development of the company's impeccable corporate reputation among stakeholders.

2. It is proved that reputation management is an important component of the company's governance system. Its independence is expressed by the specifics of the essential content of the corporate reputation, accompanied with a clear goal and objectives, as well as the justification of the importance of reputation management in the company's activities and its strategic development.

3. Reputation management is closely related to and deeply integrated with other types (components) of management, such as "public relations", "corporate communications" and "corporate relations", as a result of which they are often equated. However, these components of governance differ from each other on the basis of the purpose of their implementation and the functions they perform. It is established that the highest goal of reputation management is to build a corporate reputation and achieve the key stakeholders' loyalty.

4. The prospect of further research is to develop a theoretical and methodological basis for the information support of the reputation management system, which will provide for the effective use of accounting and analytical tools to build and develop the company's impeccable reputation in the market. 


\section{REFERENCES}

[1] Stigler G.J. Information in the Labor Market. Journal of Political Economy, 69 (1962), 49-73.

[2] Dowling G.R. Managing Your Corporate Images. Industrial Marketing Management, 15 (1986), 109-115.

[3] Caminiti S. The Payoff from a Good Reputation. Fortune, 125 (3) (1992), 49-53.

[4] Preece S.B., Fleisher C. and Toccacelli J. Building a Reputation Along the Value Chain at Levi Strauss. Long Range Planning, 28 (6) (1995), 88-98.

[5] Eidson C. and Master M. Top Ten ... Most Admired ... Most Respected: Who Makes the Call? Across the Board, 37 (2000), 16-22.

[6] Nakra P. Corporate Reputation Management: "CRM" with a Strategic Twist. Public Relations Quarterly, 45 (2) (2000), 35-42.

[7] Goldberg M.E. and Hartwick J. The Effects of Advertiser Reputation and Extremity of Advertising Claim on Advertising Effectiveness. Journal of Consumer Research, 17 (2) (1990), 172-179. doi: $10.1086 / 208547$

[8] Fombrun C.J. and van Riel C. The Reputational Landscape. Corporate Reputation Review, 1 (1-2) (1998), 5-14.

[9] Lafferty B.A. and Goldsmith R.E. Corporate Credibility's Role in Consumers' Attitudes and Purchase Intentions When a High versus a Low Credibility Endorser is Used in the Ad. Journal of Business Research, 44 (2) (1999), 109-116. doi: 10.1016/S0148-2963(98)00002-2

[10] Klein B. and Leffler K.B. The Role of Market Forces in Assuring Contractual Performance. Journal of Political Economy, 89 (1981), 615-641. Available at: http://oz.stern.nyu.edu/cite05/readings/cabral2.pdf

[11] Milgrom P. and Roberts J. Predation, Reputation and Entry Deterrence. Journal of Economic Theory, 27 (1982), 280-312. doi: 10.1016/0022-0531(82)90031-X

[12] Roberts P.W. and Dowling G.R. The Value of a Firm's Corporate Reputation: How Reputation Helps Attain and Sustain Superior Profitability? Corporate Reputation Review, 1 (1) (1997), 72-76.

[13] Shkromyda V.V. and Shkromyda N.Ya. Features of the study of the company's reputation. Scientific economic journal "Intellect XXI", 3 (2019), 110-116. Available at: http://www.intellect21.nuft.org.ua/journal/2019/2019_3/3_2019.pdf (in Ukrainian)

[14] Khamitov, N. Philosophical encyclopedic dictionary. Abris, Kyiv, 2002. ISBN 966-531-128-X (in Ukrainian)

[15] Sriramesh K. and Vercic D. The global public relations handbook: Theory, research, and practice. Routledge, 2003.

[16] Kent M.L. and Taylor M. Toward a dialogic theory of public relations. Public relations review, 28 (1) (2002), 21-37. doi: 10.1016/S0363-8111(02)00108-X

[17] Grunig J.E. Excellence in public relations and communication management. Routledge, 2013.

[18] Lattimore D. and Lattimore D. Public relations: The profession and the practice. McGraw-Hill, New York, 2004.

[19] Hutton J.G. The definition, dimensions and domain of public relations. Public Relations Review, 25 (2) (1999), 199-214. Available at: https://m92mc.files.wordpress.com/2015/01/hutton-1999public_relations_review.pdf

[20] Finn D.W., Baker J., Marshall G.W. and Anderson R. Total quality management and internal customers: measuring internal service quality. Journal of Marketing Theory and Practice, 4 (3) (1996), 36-51. doi: 10.1080/10696679.1996.11501731

[21] Ewen S. PR!: a social history of spin. Basic Books, New York, 1996.

[22] Newsom D., Turk J., and Kruckeberg D. Cengage Advantage Books: This is PR: The Realities of Public Relations. Cengage Learning, 2012.

[23] Buffett W. and Cunningham L.A. The essays of Warren Buffett: lessons for corporate America. L. Cunningham, 2001.

[24] Marken G.A. Reputation management starts at home: One day at a time. Public Relations Quarterly, 49 (2) (2004), 35-36.

[25] Genasi C. Winning reputations: how to be your own spin doctor. Springer, 2001.

[26] Wiedmann K. and Buxel H. Corporate Reputation Management in Germany: Results of an Empirical Study. Corporate Reputation Review, 8 (2005), 145-163. doi: 10.1057/palgrave.crr.1540246 
[27] Schanz K.U. Maintaining stakeholder trust in difficult times: Some fundamental reflections in light of the credit crisis. The Geneva Papers on Risk and Insurance-Issues and Practice, 34 (2) (2009), 260-270.

[28] Rodionov O.V. Approaches to defining the essence of the concept of "business reputation of the enterprise". Project Management and Production Development, 4 (16) (2005), 133-140. (in Ukrainian)

[29] Dubrova O.S. Business reputation of the enterprise: practical aspects of management. Economy and State, 12 (2009), 38-41. (in Ukrainian)

[30] Batchenko L. and Gonchar L. Reputational capital as a basis for economic growth of enterprises in the hotel and restaurant business. Restaurant and hotel consulting. Innovations, 2 (2018), 64-80. (in Ukrainian)

[31] Deeva N.E. and Grabchak V.I. Enterprise reputation management: the main factors influencing the formation and improvement. Young Scientist, 5 (32) (2016), 48-52. (in Ukrainian)

[32] Okorsky V.P. Fundamentals of management. Rivne, 2009. (in Ukrainian)

[33] Drucker P.F. Management cases. Harper Collins, 2019.

Address: Vitaliy Shkromyda, Vasyl Stefanyk Precarpathian National University, 57 Shevchenko St., IvanoFrankivsk, 76018 Ukraine.

E-mail: vitaliy.shkromyda@pnu.edu.ua

Received: October 10, 2020; revised: October 30, 2020.

Шкромида Віталій. Дискусійні аспекти впровадження репутаційного менеджменту. Журнал Прикарпатського університету імені Василя Стефаника, 7 (3) (2020), 60-67.

Визнання компанії, пізнаваність іï продукції та позитивне сприйняття серед стейкходдерів виступають вагомими драйверами сталого розвитку, які в сукупності породжують постійні продажі, забезпечують високу маржу та підсилюють конкурентні позиції на відповідному ринку. Ключовим чинником такого успіху є бездоганна корпоративна репутація компанії, значимість і роль якої все більше дослідників засвідчують у своїх публікаціях як на теоретичному, так і на практичному рівнях.

Визначено, репутаційний менеджмент як окремий компонент системи менеджменту компанії супроводжується дискусійними питаннями щодо його виокремлення та самостійності. У літературних джерелах з цього приводу простежуються різні думки серед науковців та практикуючих фахівців, які потребують узгодження. Одні дослідники відносять репутаційний менеджмент до компетенцій “зв'язки з громадськістю” та, водночас, інші - виокремдюють та доводять його самостійність як окремої системи менеджменту, яка має свою мету та конкретні завдання.

У ході дослідження доведено, репутаційний менеджмент є самостійним компонентом системи менеджменту компанії. Обгрунтування такого твердження виражається сутнісним наповненням корпоративної репутації, супроводжується чітко поставленою метою і функціями, які виконуються, а також обгрунтуванням важдивості репутаційного менеджменту у діяльності компанії та іï стратегічному розвитку. Погоджуємося, репутаційний менеджмент гдибоко інтегрований з іншими компонентами системи менеджменту, такими як “зв'язки з громадськістю”, “корпоративні комунікації" та “корпоративні відносини", внаслідок чого їх часто ототожнюють. Проте, означені компоненти системи менеджменту вирізняються один від одного як за змістом, так i за призначенням. Встановлено, найвищою метою репутаційного менеджменту є конструювання корпоративної репутації та досягнення иояльності ключових стейкхолдерів.

Науковою цінністю проведених досліджень є доповнення теоретико-метододогічної основи репутаційного менеджменту, зокрема в частині вирішення дискусійних аспектів його впровадження у діяльність компаній.

Кдючові слова: сільськогосподарські підприємства, трансформація, інтеграція, механізм, моніторинг. 